\title{
Irfani
}

ISSN 1907-0969 E ISSN 2442-8272

Volume 15 Nomor 2 Desember 2019

Halaman 76-83

http://journal.iaingorontalo.ac.id/index.php/ir

\section{PERAN LINGKUNGAN MADRASAH DALAM MENGATASI KENAKALAN SISWA}

\author{
Rahmat Hidayatullah \\ Pascasarjana IAIN Sultan Amai Gorontalo \\ email: rhidayatullah87@gmail.com
}

\begin{abstract}
ABSTRAK
Permasalahan dalam penelitian ini adalah bagaimana bentuk-bentuk kenakalan siswa, bagaimana peran lingkungan madrasah dalam mengatasi kenakalan siswa, faktor-faktor pendukung dan penghambat peran lingkungan madrasah dalam mengatasi kenakalan siswa. Adapun tujuan penelitian ini adalah untuk mengetahui bentuk-bentuk kenakalan siswa, untuk mengetahui peran lingkungan madrasah dalam mengatasi kenakalan siswa, untuk mengetahui faktor-faktor penghambat dan pendukung peran lingkungan madrasah dalam mengatasi kenakalan siswa.Metode yang digunakan dalam penelitian ini adalah pendekatan kualitatif yang menghasilkan data deskriptif berupa kata-kata dengan metode pengumpulan data adalah observasi, wawancara dan dokumentasi. Hasil penelitian menerangkan bahwa peran lingkungan madrasah dalam mengatasi kenakalan siswa dengan menerapkan peraturan tata tertib sekolah, pelanggaran terhadap kegiatan belajar mengajar, pelanggaran terhadap ketenteraman sekolah, dan pelanggaran terhadap etika pergaulan dengan warga sekolah. Upaya sekolah dalam menanggulangi kenakalan siswa dilaksanakan dalam bentuk program tahunan sekolah berbasis karakter yang meliputi: (a) Aspek pembinaan, (b) Aspek pencegahan kenakalan siswa. Faktorfaktor pendukung dan penghambat sekolah dalam mengatasi kenakalan siswa dapat dikelompokkan dalam dua faktor, yaitu: (1) kendala internal sekolah, dan (2) kendala eksternal.
\end{abstract}

Kata Kunci: Peran Lingkungan Madrasah, Kenakalan Siswa

\section{PENDAHULUAN}

Pendidikan adalah usaha sadar dan terencana untuk mewujudkan suasana belajar dan proses pembelajaran agar peserta didik secara aktif mengembangkan potensi dirinya untuk memiliki kekuatan spiritual keagamaan, pengendalian diri, kepribadian, kecerdasan, akhlak mulia, serta keterampilan yang diperlukan dirinya, masyarakat, bangsa dan negara. ${ }^{1}$ Pendidikan juga merupakan suatu proses yang dapat ditempuh melalui pendidikan formal, non formal maupun informal, sehingga dapat dinikmati oleh siapapun tanpa melihat latar belakang sosialnya. ${ }^{2}$

${ }^{1}$ Abdul Mudjieb \& Yusuf Mudzakir, Ilmu Pendidikan Islam, Cet. I (Jakarta: Kencana, 2006), h. 28.

${ }^{2}$ Sidik, Firman. "Pendidikan Humanis dan Implikasinya Dalam Pembelajaran." Tadbir: Jurnal Manajemen Pendidikan Islam 4.1 (2016): 88-95. 


\section{Irfani}

ISSN 1907-0969 E ISSN 2442-8272

Volume 15 Nomor 2 Desember 2019

Halaman 76-83

http://journal.iaingorontalo.ac.id/index.php/ir

Keberadaan madrasah sebagai salah satu institusi pendidikan Islam, secara filosofis dan histories tidak dapat dipisahkan dari keikutsertaan masyarakat dalam pendirian dan pengembangannya. Dalam sebuah tulisan dikatakan bahwa "keterikatan masyarakat terhadap madrasah lebih ditampakkan sebagai ikatan emosional dibanding ikatan rasional. Ikatan ini muncul karena bertemunya dua kepentingan. Pertama, hasrat kuat masyarakat islam untuk berperan serta dalam pendidikan terutama dalam upayanya untuk meningkatkan pendidikan anak-anak disekitar tempat tinggalnya. Kedua, motivasi keagamaan, yaitu keinginan agara anak-anak mereka selain mendapatkan pendidikan umum juga mendapatkan pendidikan agama yang cukup untuk bekal hidupnya. ${ }^{3}$

Masa remaja merupakan masa transisi dari anak-anak ke masa dewasa. Periode ini dianggap sebagai masa-masa yang amat penting dalam kehidupan seseorang, khususnya dalam pembentukan kepribadian seseorang. Pada masa transisi inilah yang menjadikan emosi remaja kurang stabil. Hall menyebut masa ini sebagai masa topan badai ("Strum and Drang)" yaitu sebagai periode yang berada dalam dua situasi: antara kegoncangan, penderitaan, asmara dan pemberontakan dengan otoritas orang dewasa dengan ciri-ciri sering dan mulai timbul sikap untuk menentang dan melawan terutama dengan orang-orang yang dekat, misalnya orang tua, guru dan sebagainya.

Masa transisi inilah yang memungkinkan remaja dapat menimbulkan masa krisis yang biasanya ditandai dengan kecenderungan munculnya perilaku-perilaku menyimpang. Perilaku menyimpang ini bisa menyimpang dari norma hukum, norma agama dan norma yang dianut masyarakat atau disebut juga dengan istilah kenakalan remaja.Oleh karena itu, masalah kenakalan remaja khususnya di kalangan siswa/ pelajar perlu mendapat perhatian dan penanganan secara berkelanjutan antara lain oleh guru, sekolah dan orang tua siswa. Terlebih pada era globalisasi dewasa ini, semakin banyak godaan dan tuntutan kehidupan yang cenderung mendorong sikap mental serta perilaku menyimpang setiap individu. Untuk menanggulangi dan mencegah munculnya perilaku menyimpang atau kenakalan dikalangan siswa, maka perlu upaya pembinaan terhadap siswa secara terintegrasi antara sekolah dengan orang tua siswa, dan masyarakat. Pembinaan ini dapat efektif dan efisien, jika dilakukan dengan tindakan konkrit oleh sekolah secara formal dalam bentuk program yang berkelanjutan baik yang bersifat kurikuler maupun ekstrakurikuler dalam upaya menanggulangi kenakalan siswa.

\section{KAJIAN TEORI}

\section{Pengertian Lingkungan}

Lingkungan adalah membentuk peserta didik dalam berinteraksi dengan berbagai lingkungan sekitarnya (fisik, sosial, dan budaya), dan utamanya berbagai sumber daya pendidikan yang tersedia agar dapat dicapai tujuan pendidikan yang optimal. ${ }^{4}$ Menurut Sartain (ahli psikologi amerika), yang dimaksud dengan lingkungan meliputi kondisi dan alam dunia ini yang dengan cara-cara tertentu mempengaruhi tingkah laku kita,

${ }^{3}$ Ainurrafiq Dawam dan Ahmad Ta'arifun Manajemen Madrasah Berbasis Pesantren, (Jakarta: Lista Fariska Putra, 2004), h. 25.

${ }^{4}$ Gunarsa, Singgih, Lingkungan Pendidikan, ( Jakarta: BPK Gunung Mulia, 2009), h. 90. 


\section{Irfani}

ISSN 1907-0969 E ISSN 2442-8272

Volume 15 Nomor 2 Desember 2019

Halaman 76-83

http://journal.iaingorontalo.ac.id/index.php/ir

pertumbuhan, perkembangan atau life processes. Meskipun lingkungan tidak bertanggung jawab terhadap kedewasaan anak didik, namun merupakan faktor yang sangat berpengaruh besar terhadap anak didik, sebab dalam suatu lingkungan disadari atau tidak pasti akan mempengaruhi anak. Pada dasarnya lingkungan mencakup lingkungan fisik, lingkungan budaya, dan lingkungan sosial. ${ }^{5}$

Lingkungan sekitar yang dengan sengaja digunakan sebagai alat dalam proses pendidikan (pakaian, keadaan rumah, alat permainan, buku-buku, alat peraga, dll), dinamakan lingkungan pendidikan. Secara umum fungsi lingkungan pendidikan adalah membantu peserta didik dalam interaksi dengan berbagai lingkungan sekitarnya, utamanya berbagai sumber daya pendidikan yang tersedia, agar dapat mencapai tujuan pendidikan yang optimal. Selain itu penataan lingkungan pendidikan tersebut terutama dimaksudkan agar proses pendidikan dapat berkembang secara efektif dan efisien.

\section{Konsep Dasar Madrasah}

Madrasah secara bahasa berasal dari akar kata darasa yaitu belajar sedangkan madrasah berarti tempat belajar atau sekolah formal. Madrasah adalah lembaga pendidikan tingkat dasar dan menengah,baik yang mengajarkan ilmu agama islam saja, perpaduan antara ilmu agama islam dan ilmu-ilmu umum, maupun ilmu yang berbasis ajaran islam. ${ }^{6}$ Madrasah adalah tempat pendidikan yang memberikan pendidikan dan pengajaran yang berada dibawah naungan Departemn Agama. ${ }^{7}$

Secara historis pendidikan madrasah berkembang dan terlahir dari dan untuk masyarakat, sehingga Malik Fadjar yang dikutip pendapatnya oleh Tilaar menyatakan bahwa "madrasah adalah madrasah". Kalimat tersebut dapat dipahami bahwa madrasah yang memiliki karakteristik tersendiri, visi dan misi yang khas dalam masyarakat dan bangsa tidak dapat diubah dan digantikan nama maupun bentuknya dengan lembaga pendidikan lainnya. ${ }^{8}$

Madrasah sebagai lembaga pendidikan Islam di Indonesia relatif lebih muda dibanding pesantren. Ia lahir pada abad 20 dengan munculnya Madrasah Manba'ul Ulum Kerajaan Surakarta tahun 1905 dan Sekolah Adabiyah yang didirikan oleh Syekh Abdullah Ahmad di Sumatera Barat tahun 1909. Madrasah berdiri atas inisiatif dan realisasi dari pembaharuan sistem pendidikan Islam yang telah ada. Pembaharuan tersebut, menurut Karl Sternbrink, meliputi tiga hal, yaitu:

1. Usaha menyempumakan sistem pendidikan pesantren

2. Penyesuaian dengan sistem pendidikan Barat

\footnotetext{
${ }^{5}$ Ibid., h. 102.

${ }^{6}$ Jamal Ma'mur Asmani, Kiat-Kiat Melahirkan Madrasah Unggulan, Cet. I, (Jogjakarta: DIVA Press, 2013), h. 19.

7 Ridlwan Nasir, Mencari Tipologi Format Pendidikan Ideal, Cet. I, (Yogyakarta: Pustaka Pelajar, 2005), h. 90.

8 H.A.R Tilaar, Paradigma Baru Pendidikan Nasional ( Jakarta : PT. Rineka Cipta, 2004) h. 169.
} 


\section{Irfani}

ISSN 1907-0969 E ISSN 2442-8272

Volume 15 Nomor 2 Desember 2019

Halaman 76-83

http://journal.iaingorontalo.ac.id/index.php/ir

3. Upaya menjembatani antara sistem pendidikan tradisional pesantren dan sistem pendidikan Barat. ${ }^{9}$

Madrasah sebagai lembaga pendidikan Islam kini ditempatkan sebagai pendidikan sekolah dalam sistem pendidikan nasional. Munculnya SKB tiga menteri (Menteri Agama, Menteri Pendidikan dan Kebudayaan, dan Menteri dalam Negeri) menandakan bahwa eksistensi madrasah sudah cukup kuat beriringan dengan sekolah umum. Disamping itu, munculnya SKB tiga menteri tersebut juga dinilai sebagai langkah positif bagi peningkatan mutu madrasah baik dari status, nilai ijazah maupun kurikulumnya. Didalam salah satu diktum pertimbangkan SKB tersebut disebutkan perlunya diambil langkah-langkah untuk meningkatkan mutu pendidikan pada madrasah agar lulusan dari madrasah dapat melanjutkan atau pindah kesekolah - sekolah umum dari sekolah dasar sampai perguruan tinggi. ${ }^{10}$

\section{Kenakalan Siswa}

Kartono mengartikan juvenil delinquency sebagai suatu perlakuan jahat (dursila), atau kejahatan/ kenakalan anak-anak muda, merupakan gejala sakit (patologis) secara sosial pada anak-anak dan siswa yang disebabkan oleh satu bentuk pengabaian sosial, sehingga dapat mengembangkan bentuk tingkah laku yang menyimpang. Delinquency menurut Kartono selalu mempunyai konotasi serangan, pelanggaran, kejahatan dan keganasan yang dilakukan oleh anak-anak muda dibawah usia 22 tahun. ${ }^{11}$

Simanjuntak memberi tinjauan secara sosiokultural tentang arti juvenile delinquency, menurutnya suatu perbuatan disebut delinkuen apabila perbuatan-perbuatan tersebut bertentangan dengan norma-norma yang ada dalam masyarakat dimana ia hidup atau suatu perbuatan yang anti sosial dimana di dalamnya terkandung unsur-unsur antinormatif. $^{12}$

Menurut Santrock kenakalan Siswa (juvenile delinquency) mengacu pada suatu rentang yang sangat luas, dari tingkah laku yang tidak dapat diterima secara sosial misalnya bersikap berlebihan di sekolah sampai pelanggaran status seperti melarikan diri hingga tindak kriminal misalnya pencurian. ${ }^{13}$

Berdasarkan definisi-definisi yang telah dikemukakan diatas, maka dapat disimpulkan kenakalan siswa adalah semua perbuatan menyimpang atau pelanggaran yang bersifat anti sosial, anti susila, pelanggaran status, melawan hukum dan menyalahi

9 Darmuin (1998). Prospek Pendidikan Islam di Indonesia: Suatu Telaah terhadap Pesantren dan Madrasah. Dalam Chabib Thoha dan Abdul Muth'i. PBM-PAI di Sekolah: Eksistensi dan Proses Belajar Mengajar Pendidikan Agama Islam. Yogyakarta: Pustaka Pelajar bekerja sarna dengan Fakultas Tarbiyah 1AIN Walisongo Semarang.

${ }^{10}$ Jalaluddin dan Said, Filsafat Pendidikan Islam: Konsep dan Perkembangan, Jakarta: Grafindo Persada. 2008), h. 78.

11 Ibid., h. 197.

12 Ancok, Djamaludin dan Fuad Nashori Suroso, Psikologi Islam Solusi Islam Atas Problem-Problem Psikologi. (Yogyakarta: Pustaka Pelajar, 2008), h. 96.

${ }^{13}$ Disti, Miftah A. dan Ritandiyono. Religiusitas dan Perilaku Seks Bebas pada Dewasa Awal. Jurnal Psikologi. Vol. 1. No. 2. h. 170-176 


\section{Irfani}

ISSN 1907-0969 E ISSN 2442-8272

Volume 15 Nomor 2 Desember 2019

Halaman 76-83

http://journal.iaingorontalo.ac.id/index.php/ir

norma-norma atau aturan-aturan yang berlaku dalam masyarakat yang dilakukan oleh siswa sehingga dapat merugikan dirinya sendiri maupun orang lain dan lingkungan sekitarnya.

\section{Jenis Jenis Kenakalan Siswa}

a. Jensen membagi kenakalan menjadi empat jenis, yaitu : Kenakalan yang menimbulkan korban fisik pada orang lain, misalnya: perkelahian, menyakiti teman seperti melakukan penganiayaan dan lain-lain.

b. Kenakalan yang menimbulkan korban materi, misalnya: perusakan, pencurian, pemerasan, menggunakan iuran sekolah (SPP) dan lain-lain.

c. Kenakalan sosial yang tidak menimbulkan korban di pihak orang lain, misalnya: menikmati karya pornografi, penyalahgunaan obat dan hubungan seks bebas.

d. Kenakalan yang melawan status, misalnya: mengingkari status anak sebagai pelajar dengan cara datang terlambat ke sekolah, membolos, tidak memakai atribut sekolah dengan lengkap, berpakaian tidak sesuai dengan aturan sekolah, berperilaku tidak sopan dengan orang tua dan guru, mencontek, keluyuran setelah pulang sekolah dan pada malam hari tanpa tujuan yang jelas, berbohong, menggunakan kendaraan bermotor tanpa memiliki surat ijin mengemudi (SIM), mengingkari status orang tua dengan cara kabur/minggat dari rumah atau membantah perintah mereka dan sebagainya. $^{14}$

\section{Penanggulangan Kenakalan Siswa} berikut:

Dalam upaya menanggulangi kenakalan siswa dapat dilakukan upaya sebagi

a. Upaya prventif adalah kegiatan yang dilakukan secara sistematis, berencana, dan terarah, untuk menjaga agar kenakalan itu tidak timbul.

b. Upaya kuratif adalah antisipasi terhadap gejala-gejala kenakalan tersebut, agar kenakalan itu tidak meluas dan merugikan masyarakat.

c. Upaya pembinaan yaitu pembinaan terhadap siswa yang tidak melakukan kenakalan, dilaksanakan di rumah, sekolah, dan masyarakat dan pembinaan terhadap siswa yang telah mengalami tingkah laku kenakalan atau yang telah menjalani sesuatu hukuman karena kenakalannya. ${ }^{15}$

\section{METODOLOGI PENELITIAN}

Penelitian ini dilakukan di SDN 5 Kec. Biluhu Kabupaten Gorontalo, menggunakan jenis penelitian kualitatitif dengan pendekatan yang digunakan adalah fenomenologis. Selanjutnya, teknik pengumpulan data yang digunakan melalui observasi, wawancara dan dokumentasi. Sedangkan teknik analisis data dilakukan melalui tiga tahapan, yaitu: reduksi data, penyajian data dan Penarikan Kesimpulan. Sedangkan untuk

\footnotetext{
${ }^{14}$ Sudarsono, Kenakalan Remaja, (Cet.VI, Jakarta Renika Cipta, 2012), h. 119.

${ }^{15}$ Sofyan S. Willis, Remaja dan Masalahnya, (Cet.III, Bndung: Alfabeta, 2012), h. 142.
} 


\section{Irfani}

ISSN 1907-0969 E ISSN 2442-8272

Volume 15 Nomor 2 Desember 2019

Halaman 76-83

http://journal.iaingorontalo.ac.id/index.php/ir

keabsahan data dilakukan dengan membandingkan data yang diperoleh dari sumber data yang satu dengan sumber data yang lain yakni antara kepala sekolah, guru dan siswa.

\section{HASIL PENELITIAN}

\section{Bentuk Kenakalan Siswa}

Dari temuan penelitian menunjukkan bahwa secara faktual ada fenomena kenakalan dikalangan siswa disekolah ini bervariasi, adapun bentuk kenakalan siswa yang terjadi di sekolah dimaksud adalah melanggar atau tidak mematuhi peraturan tata tertib sekolah, seperti kebiasaan membolos atau tidak sekolah tanpa keterangan, terlambat datang ke sekolah, kebiasaan terlambat masuk di kelas untuk mengikuti pelajaran, tidak mengikuti upacara bendera, tidak memakai seragam sekolah, membuang sampah tidak pada tempatnya, perkelahian antar siswa (teman sebaya) disekolah, mengganggu siswa lawan jenis, dan membuat corat-coret di tembok, kaca dan ditempat lain dilingkungan sekolah yang tidak semestinya.

Selain itu membuat gaduh di saat pelajaran berlangsung, tidak mengikuti pelajaran saat guru mengajar, tidak mengerjakan tugas yang diberikan guru, dan mengganggu teman atau siswa lain yang sedang belajar. Dengan kata lain bentuk kenakalan siswa di lingkungan sekolah tersebut dapat dikategorikan tergolong sedang. Artinya kenakalan siswa hanya sebatas dalam bentuk pelanggaran, yaitu pelanggaran terhadap peraturan tata tertib sekolah, pelanggaran terhadap kegiatan belajar mengajar, pelanggaran terhadap ketenteraman sekolah, dan pelanggaran terhadap etika pergaulan dengan warga sekolah.

Jadi kenakalan siswa ini tidak dapat digolongkan pada tindakan melanggar hukum formal ataupun tidak dapat digolongkan sebagai suatu tindakan kriminal. Namun demikian, sekecil apapun bentuk kenakalan siswa perlu adanya upaya pembinaan dan pencegahan sedini mungkin dari pihak sekolah, karena kebiasaan melakukan perbuatan atau tindakan yang kurang baik atau negatif jika dibiarkan akan menjadi suatu karakter atau kebiasaan yang kurang baik bagi perkembangan individu siswa itu sendiri.

Upaya preventif atau pencegahan lebih besar manfaatnya daripada upaya kuratif (penyembuhan), karena jika kenakalan itu sudah meluas amat sulit menanggulanginya. Banyak bahayanya kepada masyarakat, menghamburkan biaya, tenaga, dan waktu, sedang hasilnya tidak seberapa. Oleh karena itu, upaya preventif (pencegahan) itu sangat penting, dan kegiatan ini dilakukan secara sistematis, berencana, dan terarah, untuk menjaga agar kenakalan itu tidak timbul.

\section{Peran Lingkungan Madrasah Dalam Mengatasi Kenakalan Siswa}

Sekolah merupakan lembaga pendidikan yang penting setelah keluarga. Peran sekolah bagi pembentukan kepribadian anak sangat besar, ini terbukti dengan keberhasilan sekolah dalam membina kecerdasan, sikap, minat dan sebagainya. peran lingkungan pendidikan madrasah dalam menanggulangi kenakalan siswa meliputi aspek pembinaan dan pencegahan adalah tergolong baik walaupun belum maksimal.

Ditinjau dari aspek pembinaan termasuk dalam hal ini upaya penanggulangan terhadap kenakalan siswa, pada kenyataannya pihak madrasah/ sekolah selalu memprogramkan pembinaan bidang kesiswaan yang terintegrasi kedalam program 


\section{Irfani}

ISSN 1907-0969 E ISSN 2442-8272

Volume 15 Nomor 2 Desember 2019

Halaman 76-83

http://journal.iaingorontalo.ac.id/index.php/ir

madrasah/ sekolah, melakukan pengembangan komponen pendidikan karakter kedalam kurikulum sekolah, baik yang bersifat intrakurikuler maupun ekstrakurikuler. Selain itu pihak madrasah/ sekolah tampaknya selalu berupaya untuk meningkatkan peran aktif komunitas madrasah/ sekolah (guru, karyawan/ staf administrasi, komite madrasah/ sekolah dan orang tua/ wali siswa).

\section{Faktor-Faktor Pendukung Dan Penghambat Peran Lingkungan Madrasah Dalam Mengatasi Kenakalan Siswa}

Upaya madrasah/sekolah dalam menanggulangi kenakalan siswa dilaksanakan dalam bentuk program tahunan sekolah berbasis karakter yang meliputi aspek pembinaan dan aspek pencegahan kenakalan siswa. Penekanan program kegiatan ini adalah pada pengenalan dan penerapan nilai-nilai karakter yang diharapkan melalui intrakurikuler maupun ekstrakurikuler. Secara teknis pelaksanaan program madrasah/ sekolah berbasis karakter ini dikoordinir dan dievaluasi oleh guru-guru di madrasah/ sekolah yang bersangkutan. Adapun faktor penghambat peran lingkungan dalam mengatasi kenakalan siswa terdiri dari faktor internal dan eksternal.

Kendala internal sekolah adalah kendala yang bersumber dari dalam sekolah. Temuan penelitian menunjukkan bahwa kendala yang tergolong selalu dialami sekolah maupun guru dalam menanggulangi kenakalan siswa, antara lain: keterbatasan dalam memberikan bimbingan karakter pada siswa saat pembelajaran di sekolah, kurang proaktifnya orang tua/ wali siswa tentang riwayat kehidupan anak (siswa) sehingga guru sulit untuk membantu pemecahan kesulitannya. Selain itu ketidakterbukaan siswa yang bermasalah dalam pemberian informasi mengenai permasalahan yang dialaminya kepada guru yang menanganinya. Begitu juga kendala lain yang selalu dialami guru dalam menanggulangi kenakalan siswa melalui kegiatan ekstrakurikuler adalah keterbatasan peluang bagi siswa dalam mengembangkan bakat dan minatnya di sekolah, karena keterbatasan fasilitas untuk kegiatan kesiswaan, dan peranan perpustakaan sekolah belum maksimal.

Faktor lain yang menjadi kendala dalam menanggulangi kenakalan siswa adalah faktor eksternal, yaitu kondisi lingkungan sekitar madrasah/ sekolah, seperti dekat dengan pusat keramaian dan lokasi madrasah/ sekolah dekat dengan jalan raya. Disamping itu temuan penelitian menunjukkan bahwa tingkat sosial ekonomi rendah dikalangan orang tua/ wali siswa, cenderung memberi beban atau menekan proses perkembangan individu siswa. Siswa bersangkutan dihadapkan dengan dua kondisi, yaitu membantu pekerjaan orang tua mencari nafkah, dan menuntut ilmu di madrasah/ sekolah. Kondisi ini tentu tidak mendukung upaya guru atau madrasah/ sekolah dalam menanggulangi kenakalan siswa, bahkan kemungkinan sebaliknya akan menjadi daya tarik tersendiri atau sebagai penyebab munculnya kenakalan di kalangan siswa, misalnya bolos madrasah/ sekolah tidak mengikuti pelajaran, melakukan tindakan atau perbuatan yang tidak diinginkan dan lain sebagainya.

Munculnya berbagai bentuk kenakalan yang dilakukan atau terjadi dikalangan siswa tersebut tentu ada faktor penyebabnya. Faktor-faktor penyebab kenakalan siswa perlu diungkap secara jelas sehingga memudahkan dalam pembinaan dan pencegahannya. 


\section{Irfani}

ISSN 1907-0969 E ISSN 2442-8272

Volume 15 Nomor 2 Desember 2019

Halaman 76-83

http://journal.iaingorontalo.ac.id/index.php/ir

Dalam hubungan ini perlu dilakukan penelusuran informasi terutama pada Kepala Sekolah, guru BP/BK, serta siswa yang bermasalah terkait dengan tindak kenakalan siswa di madrasah/ sekolah.

\section{KESIMPULAN}

Berdasarkan hasil penelitian dan pembahasan diatas, dapat disimpulkan bahwa peran lingkungan pendidikan madrasah dalam mengatasi kenakalan siswa dengan cara menerapkan peraturan tata tertib sekolah serta dilaksanakan dalam bentuk program tahunan sekolah berbasis karakter yang meliputi aspek pencegahan dan aspek pembinaan kenakalan siswa.

\section{DAFTAR PUSTAKA}

Ancok, Djamaludin dan Fuad Nashori Suroso, Psikologi Islam Solusi Islam Atas Problem-Problem Psikologi. Yogyakarta: Pustaka Pelajar, 2008.

Gunarsa, Singgih, Lingkungan Pendidikan, Jakarta: BPK Gunung Mulia, 2009.

Kamaruddin, Metode Penelitian Kualitatif Cet. I, Bandung: Alfabeta, 2010.

Nashir, Agama dan Krisis Kemanusiaan Modern, Yogyakarta: Pustaka Pelajar, 2008

Sanafiah Faisal, Penelitian Kualitatif, Bandung : Refika Aditama, 2010.

Sidik, Firman. "Pendidikan Humanis dan Implikasinya Dalam Pembelajaran." Tadbir: Jurnal Manajemen Pendidikan Islam 4.1 (2016): 88-95.

Sidik, Firman. "KONSEP PENGEMBANGAN KURIKULUM PENDIDIKAN ISLAM." (2016): 100-114.

Sudarsono, Kenakalan Remaja, Jakarta : Rineka Cipta, 2007. 